\title{
IMPLEMENTATION OF RESTORATIVE JUSTICE IN INDONESIAN GENERAL COURTS(BASED ON THE DECREE OF THE DIRECTOR- GENERAL OF THE SUPREME COURT OF THE REPUBLIC OF INDONE- SIA NO. 1691/DJU/SK/PS.00/12/2020)
}

\author{
Haposan Sahala Raja Sinaga ${ }^{1} \mathbb{U}$ \\ Faculty of Law, Universitas Kristen Indonesia, Jakarta, Indonesia
}
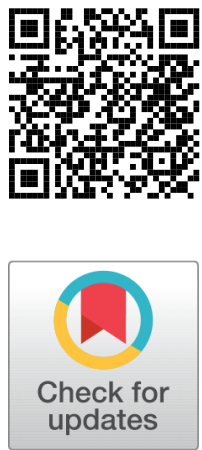

Received 3 April 2021

Accepted 18 April 2021

Published 30 April 2021

Corresponding Author

Haposan Sahala Raja Sinaga, hapo

san.sinaga@uki.ac.id

DOI $10.29121 /$

granthaalayah.v9.i4.2021.3886

Funding: This research received no specific grant from any funding agency in the public, commercial, or not-for-profit sectors.

Copyright: (C) 2021 The Author(s). This is an open access article distributed under the terms of the Creative Commons Attribution License, which permits unrestricted use, distribution, and reproduction in any medium, provided the original author and source are credited.

\section{ABSTRACT}

The shift in punishment in the criminal justice system prioritizes justice for victims and perpetrators of criminal acts in addition to alternative punishments such as social work and others carried out with a restorative justice approach. Focusing on the process of direct criminal responsibility from the perpetrator to the victim and society, if the perpetrator and victim and the community whose rights have been violated feel that justice has been achieved through collective deliberation efforts, punishment can be avoided. The perpetrator is not the main object of the restorative justice approach, but the sense of justice and conflict recovery itself are the main objects. The Supreme Court of the Republic of Indonesia, on December 22 2020, through the Director-General of the General Courts Agency, has made Decree Number: 1691/DJU/SK/PS.00/12/2020 concerning the Enforcement of Guidelines for the Implementation of Restorative Justice in the Indonesian General Courts. With the normative juridical research method, with the nature of qualitative descriptive research, by examining secondary data obtained through the Decree of the Director-General of the General Courts of the Supreme Court of the Republic of Indonesia Number: 1691/DJU/SK/PS.00/12/2020 and other related regulations which has relevance to the implementation of restorative justice in the Indonesian general courts' environment. The results of the research show the implementation of restorative justice in the Indonesian general courts, as stated in the Decree of the Director-General of the Supreme Courts Number: 1691/DJU/SK/PS.00/12/2020, which must apply and be applied by all district courts in Indonesia, especially in terms of case settlement in action. Minor offenses, child cases, women in conflict with the law and narcotics cases. The existence of alternative case resolution through restorative justice can realize the principles of fast, simple and low cost with balanced justice. 


\section{INTRODUCTION}

The 1945 Constitution of the Republic of Indonesia clearly states that the Indonesian state is based on law or recthsstaat Tahir et al. (2020); Zulkarnaen (2018). "That the rule of law is a state that places law as the basis of state power and the exercise of that power in all its forms is carried out under the rule of law" Waldron (2011). Meanwhile, "the idea of the rule of law tends towards legal positivism which has the consequence that the law must be consciously formed by the legislative body Bedner (2010).

As a state that puts law above everything else, the rule of law should aim to provide legal certainty, protect rights, and provide a sense of justice for every citizen to create order and peace. In defining the objectives of the rule of law, law enforcement officials, especially judges, mainly adhere to or are influenced by a philosophy of legal positivism Raz et al. (2013). "Legal positivism adheres to two fundamental principles, namely: First, only laws are called law, apart from laws there is no law. Second, the state or authority is the only source of law. These two principles imply that every law that legal authority has established must be considered a law that must be obeyed, regardless of the content of the law. Consequently, the law will become a tool of legitimacy for those in power in exercising and maintaining their power Tyler and Jackson (2014).

Law enforcement officials, especially judges, are shackled with a legal positivism paradigm, which is considered so far giving justice seekers injustice in upholding the law, especially criminal law enforcement. The sense of justice in society is often disturbed because enforcing criminal law is very formalistic, which in law enforcement practice places procedures as the basis of legality to uphold justice, even more, important than justice itself. Whereas currently, the public feels that law enforcement officials need to enforce criminal law by selecting minor offenses, cases of children and women who conflict with the law, and other cases that often invite reactions from the public at large Finkelhor et al. (2009).

Indeed, we often think that when dealing with crime, the criminal justice system becomes a legal instrument that can be used to tackle various forms of crime. However, the criminal justice system is different from the criminal procedural law. Andi Hamzah argues that: "The criminal procedure law on the one hand and the criminal justice system, on the other hand, is very different in scope. If the criminal procedure law is only about the law, while the criminal justice system is broader, it also includes those that are not legal" Ashworth and Zedner (2008); Carmen and Hemmens (2016). One of them is related to implementing prison development carried out by the correctional institutions as one of the sub-criminal justice systems.

In-Law Number 12 of 1995 concerning Corrections, it is stated that: "the correctional system is held to form prisoners to become fully human, aware of mistakes, improve themselves, and not repeat criminal acts so that they can be accepted back by the community". However, in its development, the guidance carried out is not optimal due to the complexity of the problems that occur in prisons. One of the root 
causes of problems in prisons is overcrowding.

Based on data from the Directorate General of Corrections at the Ministry of Law and Human Rights of the Republic of Indonesia as of March 31, 2020: "The number of prisoners and inmates in all correctional institutions and Detention Centers in Indonesia is 270,351 people. This number far exceeds the ideal capacity that can be accommodated by all prisons and detention centres, which are only 131,931 people" Sutrisno (2020). The consequences of the overcrowding include: "impacts on the poor health conditions and psychological atmosphere of prisoners and prisoners, ease of conflict between prisoners, coaching is not optimal and do not run according to regulations, and there is a swelling of the budget due to increased consumption of water, electricity and foodstuffs" Garland et al. (2009); Wener (2012).

Efforts to overcome the problem of overcrowding do not stop at increasing the capacity of prisons and detention centres. However, at least it can be started from the beginning of law enforcement with the implementation of a restorative justice approach or what is called restorative justice, namely: "a shift in punishment in the criminal justice system which prioritizes justice for victims and perpetrators of criminal acts in addition to alternative punishments such as social work and other" van Wormer (2009). "The substance of restorative justice contains the principles of building joint participation between perpetrators, victims, and community groups in resolving an event or criminal act; placing perpetrators, victims, and society as stakeholders who work together and immediately try to find solutions that are seen as fair for all parties (win-win solutions)" Loeffler and Bovaird (2020).

Restorative justice as an alternative approach to punishment is an approach that is very close to the principle of deliberation, which is the soul of the Indonesian nation. Criminalization is a last resort (ultimum remedium) that can be avoided if both parties can resolve conflicts in society by prioritizing the sense of justice of the two disputing parties. Restorative justice focuses on the process of direct criminal responsibility from the perpetrator to the victim and the community. If the perpetrator and victim and the community whose rights have been violated feel that justice has been achieved through collective deliberation efforts, punishment can be avoided. It shows that the perpetrator is not the main object of the restorative justice approach but a sense of justice and conflict recovery itself, which is the main object" "Truth $\mathrm{V}$. Justice" (2000).

Restorative justice arrangements have been regulated in various regulations, including Circular of the Chief of Police of the Republic of Indonesia Number: SE/8/VII/2018 of 2018 concerning the Implementation of Restorative Justice (Restorative Justice) in settlement of Criminal Cases, Regulation of the Chief of Police of the Republic of Indonesia Number 62019 concerning Criminal Investigation and the Republic of Indonesia Prosecutor's Regulation Number 15 of 2020 concerning Cessation of Prosecution Based on Restorative Justice. The most recent arrangement is the Decree of the Director-General of the General Courts of the Supreme Court of the Republic of Indonesia No. 1691/DJU/SK/PS.00/12/2020 concerning the 
Enforcement of Guidelines for the Implementation of Restorative Justice in the General Court on December 222020.

The Decree of the Director-General of the General Courts of the Supreme Court of the Republic of Indonesia No. 1691/DJU/SK/PS.00/12/2020 provides fresh air for applying restorative justice in Indonesia. The main decisions are: a) Order all district court judges to implement guidelines for the implementation of restorative justice in an orderly and responsible manner and b) the Chairperson of the High Court is obliged to supervise, monitor and evaluate, as well as report on the implementation of restorative justice in the jurisdiction of the High Court concerned.

This decision defines restorative justice as: "settlement of criminal cases involving perpetrators, victims, families of perpetrators/victims, and other related parties to jointly seek a fair settlement by emphasizing restoration to its original state, and not retaliation (imprisonment)." In the attachment to this Decree it is stated that "restorative justice in case resolution can be used as an instrument for restoring justice and has been implemented by the Supreme Court in the form of policy enforcement (Supreme Court Regulations and Supreme Court Circular Letters), but so far the implementation in the criminal justice system is still not optimal” Berger (2013); Murphy (2013).

It is interesting to investigate further how the implementation of restorative justice in the general court environment, which is regulated in the Decree of the Director-General of the General Courts of the Supreme Court of the Republic of Indonesia Number: 1691/DJU/SK/PS.00/12/2020 dated December 22, 2020, concerning the Enforcement of Restorative Implementation Guidelines Justice within the Indonesian General Courts. The problem that will be answered in this research is "How is the implementation of restorative justice in Indonesian general courts based on the decision of the Director-General of the Supreme Court of the Republic of Indonesia Number: 1691/ DJU/SK/PS.00/12/2020?"

\section{RESEARCH METHOD}

The research method used is to use normative juridical research methods, with qualitative descriptive research. According to Ronny Hanitijo Soemitro, normative juridical research is "literature research conducted by examining secondary data. The research was carried out by examining the provisions in statutory regulations and related literature" Soemitro (1994). Normative juridical research uses data collection tools by conducting document studies. Document study, which means studying literature theories, Decree of the Director-General of the General Courts of the Supreme Court of the Republic of Indonesia Number: 1691/DJU/SK/PS.00/12/2020 December 22, 2020, concerning Guidelines for the Implementation of Restorative Justice in the Indonesian General Courts and other related regulations relevant to the implementation of restorative justice in the Indonesian general courts. The results of the research will be presented in a descriptive-analytical manner. According to 
Soejono and Abdurrahman, descriptive analysis is "descriptive-analytical, namely describing the existing facts, then the analysis is carried out based on positive law and existing theories. The descriptive analysis focuses on solving existing problems. The implementation of this descriptive method is not limited to the stage of data collection and data preparation but includes analysis and interpretation of the meaning of the data itself" Soejono and Abdurrahman (1999).

\section{RESULT AND DISCUSSION}

The issuance of the Decree of the Director-General of the General Courts of the Supreme Court of the Republic of Indonesia Number: 1691/DJU/SK/PS.00/12/2020 dated December 22, 2020, concerning Guidelines for the Implementation of Restorative Justice in the General Court is intended to: "encourage the optimization of the implementation of Court Regulations. Agung, Surar Circular of the Supreme Court, and the Decree of the Chairman of the Supreme Court, which regulates restorative justice in court, restorative justice is to reform the criminal justice system still prioritising imprisonment. The development of the criminal system no longer relies on the perpetrator but has led to the interest alignment of the victims' recovery and the accountability of criminal acts" Ward et al. (2014).

Then the purpose of the issuance of this Decree is to: "facilitate the courts within the general court in understanding and implementing the implementation of Supreme Court Regulations, Supreme Court Circular Letters and Chief Justice of the Supreme Court which regulates the implementation of restorative justice, encouraging the increase in the implementation of restorative justice which is has been regulated by Makahamh Agung in the decision produced by the panel of judges, and the fulfilment of the principles of a trial that is fast, simple and low cost with balanced justice" Asa and Fitriasih (2018). The implementation of restorative justice must apply and be applied by all district courts in Indonesia, especially in terms of settlement of cases in minor offenses, cases of children, women in conflict with the law and narcotics cases.

Implementation of Restorative Justice in Minor Offenses Cases - Based on the Decree of the Director-General of the General Courts of the Supreme Court of the Republic of Indonesia Number: 1691/DJU/SK/PS.00./12/2020 dated December 22, 2020, concerning the Enforcement of Guidelines for the Implementation of Restorative Justice in the General Court (from now on abbreviated as "Decree") One of the criminal acts that can be applied by restorative justice is minor offenses cases. Implementation of restorative justice in minor offenses cases Armour (2012) limited to: "minor offenses as regulated in Articles 364, 373, 379, 384, 407 and Article 482 of the Criminal Code (KUHP) which are punishable by a maximum imprisonment of 3 months or a fine with a loss value of not more than Rp 2,500.000,- (two million five hundred thousand rupiah)" Rugge and Cormier (2013). 
In implementing the Decree as mentioned earlier, the Head of the District Court coordinates with the Head of the District Prosecutor's Office and the Chief of the Resort Police in carrying out the transfer of files based on the Regulation of the Supreme Court of the Republic of Indonesia Number 2 of 2012 regarding restorative justice. When receiving the delegation of cases of theft, fraud, embezzlement, and complete detention from investigators, including presenting the perpetrator, the victim, the perpetrator's family, the victim's family, and related parties on the day of the trial, the Chief Justice determines a single judge with due regard to the value of the goods or money become the object of the case as stipulated above. Then in the attachment to this Decree stipulates that: "The Chief District Court immediately assigns a single judge (1x24 hours) to examine, hear and decide the case with a quick examination procedure as regulated in Articles 205-210 of the Criminal Procedure Code. After opening the trial, the judge read out the indictment notes and asked the opinion of the defendant and the victim. Then the judge made peace efforts."

If a peace process is reached, the parties make a peace agreement, signed by the accused, victim, related parties and the peace agreement is included in consideration of the judge's decision. Settlement of minor offenses cases through restorative justice can be carried out provided that peace has been initiated between the perpetrators, victims, families of perpetrators/victims, and related community leaders who are litigating with or without compensation. If the peace agreement is unsuccessful, the sole judge will continue the examination process. During the trial, the judge continues to strive for peace and prioritizes restorative justice in his decisions. Restorative justice does not apply to perpetrators of repeated crimes following statutory provisions.

Implementation of Restorative Justice in Child Cases - So far, case handling refers to Law of the Republic of Indonesia Number 11 of 2012 concerning the Criminal Justice System for Children, Government Regulation Number 65 of 2015 concerning Guidelines for the Implementation of Diversion and Handling of Children Not Aged 12 Years Old, Regulation of the Supreme Court of the Republic of Indonesia Number 4 of 2014 concerning Guidelines for the Implementation of Diversion in the Juvenile Criminal Justice System. The juvenile criminal justice system must prioritize the restorative justice approach. Every diversion determination (case settlement out of court) is a form of restorative justice. If the diversion does not work or does not meet the requirements for diversion, the judge will seek a decision using a restorative justice approach as regulated in Articles 71-82 of Law Number 11 of 2012 concerning the Juvenile Criminal Justice System.

However, this Decree stipulates that: "after reading the indictment, the judge proactively encourages the child/parent/legal advisor and the victim and related parties (Community Guidance of the Correctional Center, Social Workers, Community Representatives) to seek peace. In case the peace process is reached, the parties make a peace agreement. Furthermore, the child and/or family, victim and related parties are signed, and the peace agreement is included in consideration of 
the judge's decision in the child's best interest. Suppose a judge imposes a sentence in the form of action. In that case, the judge is obliged to clearly and designate a place or institution in coordination with the Community Guidance of the Correctional Center, Social Workers, and the Regional Technical Implementation Unit for the Protection of Women and Children.

In the case of child offenders who are not yet 14 years old and facing legal problems, they can only be subject to non-criminal action, which includes: return to parents, surrender to someone, treatment at a mental hospital, treatment at Social Welfare Organizing Institutions, obligation to attend formal education and/or training held by the government or private bodies, the revocation of driving licenses, and repairs as a result of the crime.

Implementation of Restorative Justice in Cases of Women Facing the Law Women Dealing with the law are defined as: "women in conflict with the law, women as victims, women as witnesses or women as parties" Allen and Bradley (2018). In examining cases of women in conflict with the law, judges consider gender equality and non-discrimination by identifying trial facts, such as inequality of social status between the litigating parties, inequality of legal protection that has an impact on access to justice, discrimination, psychological impacts experienced by victims, powerlessness. The victim's physical and psychological condition, power relations that render the victim/witness helpless, and a history of violence from the perpetrator against the victim/witness.

Following Article 5 of the Supreme Court Regulation of the Republic of Indonesia Number 3 of 2017 concerning Guidelines for Adjudicating Women's Cases Against the Law: "Judges are prohibited from showing attitudes or issuing statements that denigrate, blame and/or intimidate women in conflict with the law; justify discrimination against women by using culture, customary rules and other traditional practices or using gender-biased expert interpretations; question and/or consider the experience or sexual background of the victim as a basis for releasing the perpetrator or reducing the punishment of the perpetrator, and issue statements or views that contain gender stereotypes" Saraswati (2021).

This Decree stipulates: "Judges should try women's cases against the law based on Article 6 of the Regulation of the Supreme Court of the Republic of Indonesia 3 of 2017 concerning Guidelines for Adjudicating Women's Cases." When trying cases of women facing the law as perpetrators, judges are obliged to consider legal facts using a restorative justice approach. If, as a victim, the judge must consider legal facts and implications in the future with a restorative justice approach.

The judge must also consider the losses suffered by the victim and the impact of the case, and the victim's recovery needs. Then, "The judge is obliged to inform the victim about his rights regarding restitution and compensation as stipulated in Article 98 of the Criminal Procedure Code and other provisions. The court is obliged to provide a list of Peksos (professional Social Workers) in coordination with the local social service Qonitah (2018). 
If somebody experiences physical and psychological obstacles requiring assistance, the judge is obliged to order the presence of an assistant for him. The court is obliged to provide a list of assistants according to their needs based on expert opinion (psychiatrists, doctors, psychologists and families) by filling in the personal assessment form provided at the One-Stop Integrated Service desk. In examining cases of women in conflict with the law, judges may order their statements to be heard through audits by long-distance audio-visual communication at local courts or in other places based on Article 10 of the Supreme Court Regulation of the Republic of Indonesia Number 3 of 2017.

Implementation of Restorative Justice in Narcotics Cases - For narcotics cases, the restorative justice approach can only be applied to addicts, abusers, victims of abuse, dependence on narcotics, and one day use of narcotics as regulated in Article 1 of the Joint Regulation of the Chief Justice of the Supreme Court, Minister of Law and Human Rights, Minister of Health, Minister of Social Affairs, Attorney General, Chief of Police, Head of the National Narcotics Agency Number 01/PB/MA/111/2014, Number 03 of 2014, Number 11 of 2014, Number 03 of 2014 Number Per005/A/JA/03/2014 Number 1 of 2014, Number Perber/01/111/2014/BNN concerning Handling of Narcotics Addicts and Victims of Narcotics Abuse into Rehabilitation Institutions.

This Decree stipulates that: "In the trial process, the Panel of Judges may order narcotics addicts and victims of narcotics abuse to perform medication, treatment and recovery at medical rehabilitation institutions and/or social rehabilitation institutions. The court is obliged to provide a list of medical or social rehabilitation institutions in coordination with the National Narcotics Agency".

Restorative justice in narcotics cases can be applied if it meets the requirements, namely when caught red-handed by National Police investigators and/or National Narcotics Agency investigators found evidence of 1-day use in the form of: a) Maximum 1 gram of methamphetamine; b) Ecstasy maximum eight items; c) Heroin is a maximum of 1.8 grams; d) Maximum cocaine 1.8 grams; e) Cannabis a maximum of 5 grams; f) Koka leaves a maximum of 5 grams; g) Meskalin a maximum of 5 grams; h) The maximum psilocybin group is 3 grams; i) The maximum LSD group is 2 grams; j) The maximum PCP group is 3 grams; k) Maximum fentanyl group 1 gram; l) The maximum methadone group is 0.5 grams; $\mathrm{m}$ ) The maximum morphine group is 1.8 grams; n) The maximum pethidine group is 0.96 grams; o) The maximum codeine group is 72 grams; and p) The maximum bufrenorfin group is 32 grams.

Then, the Registrar ensures that the Prosecutor has attached the assessment results from the Integrated Assessment Team to each delegation of case files charged following Article 103 paragraph (1) and Article 127 of the Republic of Indonesia Law Number 35 of 2009 concerning Narcotics. If the case files when they are submitted are not completed with the results of the assessment, the judge during the trial may order the Prosecutor to attach the results of the assessment from the Integrated Assessment Team. The judge may order the defendant to present his family and 
related parties to hear their testimony as mitigating witnesses in the framework of a restorative justice approach.

The Court as A Final Institution in Terms of Determining Decisions on The Fate of a Person - "The court is still considered part of the formal legal system independent of society, so the court should change its perspective from this opinion. As an institution appointed by the state, it can be said to be appointed by God to be able to decide with a conscience entrusted by God and the state as regulated in Law of the Republic of Indonesia Number 49 of 2009 concerning Judicial Power" Pildes (2011).

In Article 4 Paragraph (1) of Law of the Republic of Indonesia Number 49 of 2009 concerning Judicial Power, it is explained that "Justice is carried out for the sake of justice based on the one and only God" Perelman (2012). From this, the judge is indirect "directly responsible to God in deciding a case, so that the law requested by the public, which is the main part of the state and as the source of the law, can become a matter of consideration in deciding, is not the people's voice a God's voice (vox populi vox Dei)" Smorchkov et al. (2020). So that as regulated in Article 28 paragraph (1) Law of the Republic of Indonesia Number 48 of 2009 concerning Judicial Power that "Judges are obliged to explore, follow and understand the legal values and the sense of justice that live in a society" Faisal et al. (2020).

\section{CONCLUSION}

The implementation of restorative justice in the Indonesian general courts environment as stated in the Decree of the Director-General Courts Number: 1691/DJU/SK/PS.00/12/2020 dated December 22, 2020, concerning the Enforcement of Guidelines for the Implementation of Restorative Justice in the General Courts must apply and be applied by all District courts in Indonesia, especially in matters of settlement of cases in minor offenses, cases of children, women in conflict with the law and cases of narcotics. It is hoped that alternative case resolution through restorative justice can realize the principles of fast, simple and low cost with balanced justice. In the future, it remains only to wait at the level of implementation at law enforcement officials to understand better and be able to apply restorative justice efforts in the criminal justice system as a solution to overcrowding problems in prisons and alternative solutions to criminal cases that have been too formalistic and positivistic so far.

\section{REFERENCES}

Allen, E., \& Bradley, M. S. (2018). Perceptions of Harm, Criminality, and Law Enforcement Response: Comparing Violence by Men Against Women and Violence by Women Against Men. Victims \& Offenders, 13(3), 373-389. Retrieved from https://dx.doi.org/ 10.1080/15564886.2017.1340383 10.1080/15564886.2017.1340383

Armour, M. (2012). Restorative Justice: Some Facts and History. Tikkun, 27(1), 2565. Retrieved from https://dx.doi.org/10.1215/08879982-2012-1012 10.1215/ 
08879982-2012-1012

Asa, S., \& Fitriasih, S. (2018). Abuse of substance, restorative justice and diversion. Abuse of substance, restorative justice and diversion. Law and Justice in a Globalized World.

Ashworth, A., \& Zedner, L. (2008). Defending the Criminal Law: Reflections on the Changing Character of Crime, Procedure, and Sanctions. Criminal Law and Philosophy, 2(1), 2151. Retrieved from https://dx.doi.org/10.1007/s11572-007-9033-2 10.1007/s11572 -007-9033-2

Bedner, A. (2010). An Elementary Approach to the Rule of Law. Hague Journal on the Rule of Law, 2(01), 48-74. Retrieved from https://dx.doi.org/10.1017/s1876404510100037 $10.1017 / \mathrm{s} 1876404510100037$

Berger, R. (2013). Congress v. The Supreme Court. Congress v. the Supreme Court.

Carmen, R. V. D., \& Hemmens, C. (2016). Criminal procedure: Law and practice. Cengage Learning. Criminal procedure: Law and practice.

Faisal, F., Abdullah, A. G., \& Sudiro, A. (2020). Legal Discovery of Judges in the Criminal Cases of Narcotic Abuse Based on Law Number 35 of 2009. PalArch's Journal of Archaeology of Egypt/Egyptology, 17(2), 98-106.

Finkelhor, D., Ormrod, R., \& Chaffin, M. (2009). Juveniles Who Commit Sex Offenses Against Minors. Juveniles Who Commit Sex Offenses Against Minors.

Garland, B. E., Mccarty, W. P., \& Zhao, R. (2009). Job satisfaction and organizational commitment in prisons: An examination of psychological staff, teachers, and unit management staff. Criminal Justice and Behavior, 36(2), 163-183.

Loeffler, E., \& Bovaird, T. (2020). Assessing the impact of co-production on pathways to outcomes in public services: the case of policing and criminal justice. International Public Management Journal, 23(2), 205-223. Retrieved from https://dx.doi.org/10.1080/ $10967494.2019 .166889510 .1080 / 10967494.2019 .1668895$

Murphy, E. (2013). The politics of privacy in the criminal justice system: Information disclosure, the Fourth Amendment, and statutory law enforcement exemptions. Michigan Law Review, 111(4), 485-546.

Perelman, C. (2012). Justice, law, and argument: Essays on moral and legal reasoning. Justice, law, and argument: Essays on moral and legal reasoning, 142.

Pildes, R. H. (2011). Is the Supreme Court a "Majoritarian" Institution? (Vol. 2010). University of Chicago Press. Retrieved from https://dx.doi.org/10.1086/658919 10.1086/ 658919

Qonitah, N. (2018). Institutionalised or Deinstitutionalized? (A Paradigm Shift to Practice in Social Workers' Views) (Doctoral dissertation. Psychology and Social Work.

Raz, J., Kavanagh, A., \& Oberdiek, J. (2013). Legal positivism and the sources of law. Legal positivism and the sources of law. Arguing About Law, 117-117.

Rugge, T., \& Cormier, T. (2013). Restorative justice in cases of serious crime: an evaluation. Restorative justice in cases of serious crime: an evaluation. New directions in restorative justice: Issues, practice, evaluation, 266-277.

Saraswati, R. (2021). Restorative justice in cases of serious crime: an evaluation. Gender Bias in Indonesian Courts: Is Perma No. 3 of 2017 the Solution for Gender-Based Violence Cases? Laws, 10.

Smorchkov, A. M., Fedorchenko, S. N., \& Shkarenkov, P. P. (2020). Vox Populi-Vox Dei: Elections in the Roman Republic and Modern Democracies (Comparative Analysis). Новый исторический вестник(4), 129-139.

Soejono, A., \& Abdurrahman, H. (1999). A research method of thought and implementation. In $A$ research method of thought and implementation. Jakarta: Rineka Cipta. 
Soemitro, R. H. (1994). Legal and Jurimetric Research Methodology, Fifth Printing. In Legal and Jurimetric Research Methodology, Fifth Printing. Jakarta: Ghalia Indonesia.

Sutrisno, A. E. (2020). Hacking Assimilation Policies for Prisoners. Hacking Assimilation Policies for Prisoners. Retrieved from http://www.ditjenpas.go.id/meretas-kebijakan -asimilasi-bagi-narapidanaon22Maret2021

Tahir, A., Luthviati, I. S. F. R. D., \& Kadir, R. S. A. (2020). The Model of Criminal Policy to Customary Law Society after Decision of the Constitutional Court of the Republic of Indonesia Number 95/PUU-XII/2014. International Journal of Advanced Science and Technology, $29(4), 1581-89$.

Truth v. Justice. (2000). In Rotberg, R. I., Thompson, \& D. (Eds.), Truth v. Justice: The Morality of Truth Commissions: The Morality of Truth Commissions. Princeton University Press.

Tyler, T. R., \& Jackson, J. (2014). Popular legitimacy and the exercise of legal authority: Motivating compliance, cooperation, and engagement. Psychology, Public Policy, and Law, 20(1), 78-95. Retrieved from https://dx.doi.org/10.1037/a0034514 10.1037/ a0034514

van Wormer, K. (2009). Restorative Justice as Social Justice for Victims of Gendered Violence: A Standpoint Feminist Perspective. Social Work, 54(2), 107-116. Retrieved from https://dx.doi.org/10.1093/sw/54.2.107 10.1093/sw/54.2.107

Waldron, J. (2011). The rule of law and the importance of procedure. NOMOS: Am. Soc'y Pol. Legal Phil, 50, 3-3.

Ward, T., Fox, K. J., \& Garber, M. (2014). Restorative justice, offender rehabilitation and desistance. Restorative Justice, 2(1), 24-42. Retrieved from https://dx.doi.org/10.5235/ 20504721.2.1.24 10.5235/20504721.2.1.24

Wener, R. (2012). The environmental psychology of prisons and jails. The environmental psychology of prisons and jails: Creating humane spaces in secure settings.

Zulkarnaen, A. H. (2018). Industrial Relations Instrument in the Concept of Law State (Rechtsstaat) Which Based on Pancasila in Indonesia. Journal of Legal, Ethical and Regulatory Issues, 21-21. 